\title{
Prinsip Mattulu Tellue Pada Masyarakat Bone Dalam Perspektif Al-Qur'an
}

\author{
Mahadir \\ Rosmini \\ Ahmad Mujahid \\ Universitas Islam Negeri Alauddin Makassar \\ e-mail: mahmudmahadir@gmail.com
}

\begin{abstract}
Viewing Bone People's Principle of Mattulu Tellue from the Perspectives of Al-Quran; This study aims to describe andto know as well as to understand and to analyze Mattulu tellue principle in Bugis Bone people.In this case, it is expected to understand Matullu tellue principle in terms of its content, origins, contextualization, relationships as well as the response of the Qur'an into it.This research is a field study research using qualitativedescriptive design. In terms of its approaches, the historical, sociological, and cultural anthropological approaches were empoyed by the researcher, while the method of interpretation used was maudūininterpretation method. Data were manually processed and collected through documentation, observation, and interviews. Data gained through those three data sets were then analysed using stages of data reduction, data presentation, and data conclusion drawing. The validity of the data was then tested using persistent observation and triangulation techniques. The findings of this study indicate that mattulu tellue, namely mali siparappe (washed to wash up each other), rebba sipatokkong (collapsed to uphold each other), malilu sipakainge(sinned to remind each other) is one of the Bugis Bone cultures legitimized in the daily life of Bone people. This principle leads to the concept of helping and mutual collaboration among people which hasbecome moral values inherited from the ancestor not only as a norm but also as a motto and a philosophy of life of Bugis Bone people in the hope of creating the unity. Mattulu tellue is not
\end{abstract}

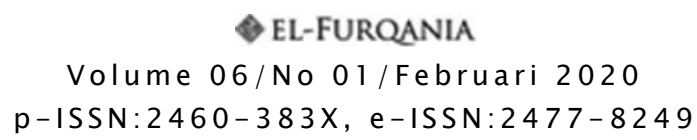


only a living principle by harmonizing the concepts and values of its teachings into the cultural mind, but it is also in line with the Qur'anic intellectual tradition which has become an integral part of Islamic law because it comes with Islamic values as contained in several verses of the Qur'an.

KeyWords: Cultural Principle, Mattulu Tellue, Siparappe, Sipatokkong, Sipakainge, Bugis Bone,Mutual Collaboration, Unity, Helping, al-Qur'an.

\section{Prolog}

Bone merupakan bagian dari suku Bugis memiliki suatu pegangan hidup secara khas yang telah menjadi prinsip kehidupan sebagai perisai dalam menjaga keberlangsungan nilai-nilai yang dimilikinya, yaitu prinsip Mattulu Tellue yang menjadi sebagai simbol keutuhan dan kekuatan. Prinsip yang ada dalam mattulu tellue yaitu Mali Siparappe, Rebba Sipatokkong, Malilu Sipakainge yang mengandung makna "Hanyut saling dampat mendaparkan, jatuh saling menegakkan, khilaf saling mengingatkan".

Nilai yang dikandung dari konsep mattulu tellue tersebut merupakan sebuah konsep sosial yaitu tolong-menolong dan kerja sama. Konsep ini memberitahu akan pentingnya bantuan orang lain serta hubungan timbal baliknya.

Islam sebagai satu-satunya agama yang dilegalkan Allah, tentunya mempunyai sistem etika dalam masyarakat luas yang kemudian disebut etika sosial. Demikian halnya mattulu tellue, tidak hanya sebagai prinsipiel Bugis Bone sebagai moto hidup yang menyelaraskan konsep dan nilai ajarannya ke dalam alam pikiran budayanya, namun ia juga sejalan dengan tradisi keintelektualan Islam. Hal ini ketika melihat lebih jauh, hal yang sama bisa ditemukan dalam al-Qur'an, bahwa manusia sangat dianjurkan untuk saling menolong, bantu membantu, gotong royong dan jalan bersama.

${ }^{1}$ Christian Pelras, The Bugis, terj. Abdul Rahman Abu, et. al., Manusia Bugis (Cet. I; Jakarta: Nalar, 2006), h. 248. Lihat pula A. Hasan Machmud, Silasa I (Cet. III; Makassar: UD. Indah Jaya, 2001), 43. 
Maka pada tataran ini, ditemukan signifikansi kontekstualisasi kebudayaan Bone salah satunya prinsip mattulu tellue dalam penegakan ajaran al-Qur'an pada masyarakat Bugis Bone. Hal ini dimaksudkan untuk mencari dan merumuskan konsep nilai al-Qur'an yang rahmatan li al-'ālamīn. Dengan demikian, kontekstualisasi mattulu tellue menjadi tuntutan yang harus direspon untuk memfasilitasi terciptanya atmosfir sosial yang memberikan ruang dan peluang terjadinya proses kreativitas budaya dengan penegakan nilai al-Qur'an pada masyarakat Bugis Bone yang beradat.

Bertolak dari pemaparan di atas, penelitian ini bertujuan untuk mendeskripsikan, mengetahui, memahami dan menganalisis tentang prinsip mattulu tellue, kontekstualisasinya pada masayarakat Bugis Bone dan relevansinya dalam al-Qur'an.

\section{Tinjauan Teoritis}

Mattulu Tellue berasal dari kata "situlu tellu" dalam bahasa Bugis berarti "saling bertaut tiga" yang disimbolkan bagaikan seutas tali, yang pada selanjutnya melahirkan arti mattulu tellue sesuatu atau tali yang saling bertaut tiga yang dijadikan simbolis keutuhan dan kekuatan.

Mattulu tellue di Kabupaten Bone banyak bentuk dan pahamnya.Adapun bentuk mattulu tellue; mali siparappe, rebba sipatokkong, malilu sipakainge merupakan prinsip tatanan adat orang Bugis yang mengarah pada konsep tolong menolong dan bekerja sama. Dikatakan pula bahwa,mattulu tellue merupakan prinsip yang di dalamnya terkandung sebuah nilai-nilai kebaikan karena tendensi pada mattulu tellue ini adalah pesan untuk saling menopang satu sama lain.Selai itu pula, bahwa mattulu tellue ini adalah pesan moral dari leluhur yang menjadi falsafah hidup Bugis Bone yang mengharapkan adanya persatuan.

Substansi dari mattulu tellue yang disebutkan di atas, di samping ia sebagai wujud tolong menolong dan kerja sama, juga masuk dalam ranah sipakatau dan sipakalebbi yaitu prinsip yang mengupayakan di antara sesama itu untuk saling mengangkat atau 
menopong satu sama lain dan juga prinsip untuk saling menghargai dan menghormati satu sama lain.

Sebelum mattulu tellue ini prinsip yang lebih familiar lebih dahulu dikenal adalah prinsip ' $3 \mathrm{~S}$ ' yaitusipakatau, sipakalebbi dan sipakainge yang sejak dipakai Raja Bone VII Latenrirawe Bongkangnge (1560-1578 M.), namun karena kondisi berada dalam keadaan malapetaka, marabahaya atau suatu kondisi di mana masyarakat yang mungkin pada saat itu sedang kacau balau, maka lahirlah "mali siparappe" artinya hanyut saling mendamparkan,seandainya kamu mengalir di sungai maka marilah saling mengait untuk dibawa atau diangkat atau dengan maksud lain agar tidak terbawa arus lebih jauh; "rebba sipatokkong" artinya rebah saling menegakkan, narekko engka tuju-tujuko na nulle mopa patokkongko maka marilah saling bergotong-royong; dan "malilu sipakainge"artinya khilaf saling memperingati, apabila salah seorang berbuat salah dan khilaf maka haruslah saling memperingati atau saling menyadarkan.

Dikalangan Bugis Bone, prinsip mattulu tellue telah digunakan tidak hanya sebagai salah satu moto hidup namun juga dalam ranah kepemerintahan pada masa Raja Bone VII Latenrirawe Bongkangnge (1560-1578 M), yang diprakarsai oleh sang diplomat ulung dari Tana-Bone yang bernama La Mellong, dikenal dengan gelar Kajao Lalliddong.

Dalam sejarah, Kajao Lalliddong tersebut banyak menciptakan dan melahirkan konsep-konsep kepemimpinan sebagai norma-norma adab yang dijadikan sebagai anutan khususnya oleh raja dan masyarakat pada umumnya dalam menjalankan sekaligus menjaga keutuhan negeri di Tana-Bone. Norma-norma itu dikalangan suku Bugis dikenal sebagai pangadereng. Sebagaimana yang telah disebutkan pangadereng lahir berawal dari dialog antara Raja dengan Kajao Laliddong yang sehubungan itu pula lahirnya pappaseng. ${ }^{2}$

\footnotetext{
${ }^{2}$ Selain dari pappaseng (pesan), terdapat pula pappangaja (nasihat); Kedua prinsip ini merupakan sumber nilai dalam budaya Bugis, penjelajahan yang telah dilakukan pada mitos manurung pada masyarakat Bugis telah mengungkapkan beberapa nilai
} 
Dalam menjaga eksistensi nilai-nilai pangadereng dan pappaseng tersebut, maka dibangunlah sebuah prinsip yang dilegitimasi dalam tatanan kehidupan masyarakat Bugis Bone salah sat unya adalah prinsip mattulu tellue.

Mattulu tellue merupakan bagian dari prinsip masyarakat Bugis Bone yang dalam sejarah Bone benih-benih dari prinsip-prinsip ini telah ada sejak Mata Silompoe Manurunge ri Matajang menjadi Raja Bone I (1300-1370 M.), namun belum dikenal sebagai 'mattulu tellue' ia baru dikenal sebagai suatu konsep ketika La Mellong menjadi penasihat Raja Bone VII, La Tenrirawe Bongkange (15601578 M.). Asas dari konsep tersebut pada masanya adalah ${ }^{3}$

1) Siattinglima; yang berarti bergandengan tangan. Maksudnya adalah hendaknya dalam mengerjakan suatu hal dilakukan secara bersama-sama.

2) Sitonraola; yang berarti berjalan searah. Maksudnya adalah satu padu atau satu kata dalam mufakat ataukah dalam artian suatu hal permasalahan hendaknya diputuskan dengan musyawarah.

3) Tessibelleang, yang berarti tidak saling menghianati. Bahwa segala sesuatu yang telah dimufakati sebagai keputusan bersama maka siapapun harus menaatinya.

Pada masa-masa selanjutnya konsep mattulu tellue yang dipopulerkan Kajao Laliddong tersebut semakin hari semakin dilupakan, hal ini karena besarnya arus pergolakan politik terutama ketika rakyat Bone dipimpin langsung dibawah aturan Kerajaan Gowa, yakni sejak masa setelah pemerintahan Raja Bone XIII La Maddaremmeng,Matinroe ri Bukaka (1631-1640 M.) hingga dipekerjakan paksanya rakyat Bone oleh Kerajaan Gowa dimasa

yang mengawali pembentukan kebudayaan Bugis.Nilai-nilai ini dicipatakan karena dimuliakan oleh leluhur mereka sebagai peletak dasar masyarakat dan kebudaan Bugis.Kemudian dialihkan turun-temurun dari satu generasi kegenerasi berikutnya, dalam usaha mewariskannya mereka menasihatkan atau memesankan, dan nasihatnasihat ini dicatat dalam lontara yang kemudian disebut pangaja dan paseng. Lihat A. Rahman Rahim, Nilai-Nilai Utama Kebudayaan Bugis (Cet. III; Makassar: Hasanuddin University Press, 1992), h. 83-84.

${ }^{3}$ A. Hasan Machmud, Silasa I, h.45-46. Pada konsep mattulu tellue ini disebutkan bahwaia merupakan salah satu sastra Bugis yang terdapat dalam sastra La Galigo. 
Karaeng Summanna menjadi pelaksana tugas Raja Gowa XV I Mannutungi Daeng Mattola, Karaeng Lakiung Sultan Malikusaid kala itu. Seiringan dengan masa tersebut, La Tenritatta muncul sebagai orang yang mampu memimpin rakyat Bone dan disebut-sebut akan mengembalikan kedaulatan Tana-Bone, sehingga Arung Amali sendiri sebagai pelaksana tugas Raja Gowa yang menggantikan Kareng Summanna kala itu, mempercayai dan menyerahkan kepemimpinannya kepada La Tenritatta, yang kemudian dikenal sebagai Arung Palakka (Raja Bone XV) sang pembebas rakyat TanaBone. ${ }^{4}$

Seiringan dengan hal di atas pula, pada masa-masa ini ia kembali menumbuhkan jiwa dan semangat ke-tobone-an (assitobonengeng/assisompungeng to Bone'e) dengan prinsipmattulu tellue namun dengan asas yang berbeda, yaitu; Mali Siparappe, Rebba Sipatokkong, Malilu Sipakainge. Tiga rangkaian frasa ini merupakan suatu rangkaian bahasa yang utuh dan luas. Dalam artian, tiga rangkaian frasa tersebut terdapat banyak interpretasi terhadapnya. Hal ini disebabkan sifatnya dinamis sesuai dengan kehidupan manusia terkhusus pada orang Bugis Bone. Maka tidaklah berlebihan bahwamattulu tellue disebut juga sebagai falsafah hidub Bugis Bone.

\section{Metodologi Penelitian}

Dalam usaha memaparkan perihal mattutlu tellue yaitu siparappe, sipatokkong dan sipakainge di Kabupaten Bone dalam basis ajaran al-Qur'an, maka penelitian ini termasuk dalam kategori penelitian studi lapangan (field research).

Penelitian ini berjenis kualitatif (qualitative research), karena dari segi pengukuran dan analisisnya akan diupayakan untuk menganalisis kehidupan sosial dengan mendeskripsikan dunia sosial dari sudut pandang atau interpretasi individu (informan) dalam latar

\footnotetext{
${ }^{4}$ Uraian lebih lanjut lihat Mattulada, Latoa: Satu Lukisan Analitis terhadap Antropologi Politik Orang Bugis(Cet. II; Makassar: Hasanuddin University Press, 1995), h. 84. Serta Dinas Kebudayaan dan Pariwisata Kabupaten Bone, Sejarah Bone (Watampone: Dinas Kebudayaan dan Pariwisata, 2007), h. 70-71.
} 
alamiahnya. ${ }^{5}$ Dalam penyajiannya akan didesain secara deskriptif (descriptive research) sebagaimana pada jenis kualitatif yang disebutkan, tujuannya tidak dimaksudkan untuk menguji sebuah hipotesis melainkan untuk mendeskripsikan suatu keadaan atau fenomena-fenomena yang diteliti secara apa adanya yang diarahkan untuk memaparkan sebuah fakta kejadian yang sistematis dan akurat. ${ }^{6}$

Dalam rangka meneliti mattulu tellue sebuah warisan budaya lokal Bugis Bone, maka akan dilaksanakan di Kabupaten Bone tepatnya di Kota Watampone.Pemilihan dan penentuan lokasi penelitian tersebut dilakukan secara sengaja (purpose sample) dengan pertimbangan bahwa Kota Watampone yang berarti pusatnya Bone yang sudah tentu merupakan daerah sentral bagi Kabupaten Bone.

Pendekatan penelitian dilakukan secara multidisipliner (multidisciplinary approach).Pendekatan-pendekatan tersebut adalah pendekatan historis, ${ }^{7}$ sosiologis, ${ }^{8}$ antropologi-budaya ${ }^{9}$ dan pendekatan tafsirmaudū

Data dikumpulkan melalui dokumentasi, observasi dan interview, diolah secara manual dengan menghimpun informasi hasil dari ketiga kumpulan data tersebut, kemudian dianalisis dengan menggunakan langkah reduksi data, penyajian data dan selanjutnya

\footnotetext{
${ }^{5}$ Dengan kata lain, penelitian kualitatif berupaya memahami bagaimana seorang individu melihat, memaknai atau menggambarkan dunia sosialnya. Pemahaman inilah yang kemudian menjadi hasil dari sebuah interaksi sosial yang merupakan esensi dari penelitian kualitatif. Lihat Sudaryono, Metodologi Penelitian (Cet. I; Jakarta: Rajawali Pers, 2017), 91.

${ }^{6}$ Sudaryono, Metodologi Penelitian, 88.

${ }^{7}$ Secara umum dipahami bahwa pendekatan historis merupakan penelaahan atas sumber-sumber lain yang berikan informasi mengenai masa lampau yang dilaksanakan secara sistematis.

${ }^{8}$ Pendekatan ini digunakan untuk mengamati dan mengalisis interaksi masyarakat, struktur sosial, struktur budaya, pranata sosial, stratifikasi sosial, perubahan sosial dan lainnya.

${ }^{9}$ Pendekatan ini digunakan untuk memahami manusia dan kebudayaannya. Antropologi akan menyadarkan tentang sebuah kesatuan dan persatuan manusia secara esensial, karenanyalah mengakibatkan adanya wujud saling menghargai satu sama lain.
} 
menarik sebuah kesimpulan. Keabsahan datanya diuji dengan menggunakan teknik persistent observation dan teknik triangulation. Teknik persistent observation yaitu bertujuan untuk memahami secara mendalam dengan melakukan pengamatan secara berulangulang agar data yang dikumpulkan betul-betul sesuai dengan fakta yangterjadi di lapangan. Sedangkan teknik triangulation (triangulasi) yaitu mengecek kebenaran data tertentu dengan membandingkan data yang telah diperoleh dari sumber lain. Triangulasi menurut Bahar Akkase digunakan atau dilakukan untuk mengecek data yang terdiri dari sumber, metode dan waktu. ${ }^{10}$

\section{Prinsip Mattulu Tellue Pada Masyarakat Bone Dalam Perspektif Al- Qur'an}

Ketika al-Qur'an hadir dan menjadi pedoman di komunitas Islam Bugis Bone, maka kebudayaan dan adat istiadat Bone yakni pangadereng dan pappaseng tidak serta merta berubah namun ia dielaborasi dan diwarnai dengan nuansa Qur'ani. Begitu pula dengan kaitannya mattulu tellue sebagai produk budaya yang menjadi perisai dalam menjaga eksistensi dari pangadereng dan pappaseng tersebut maka tentu nilai-nilai yang dikandungnya pula berlandaskan alQur'an. Walaupun sejatinya mattulu tellue ini yang diultimatumkan oleh La Tenritatta, dipengaruhi oleh La Mellong yang semasa hidupnya belum mengenal Islam, namun yang dipetuahkan oleh La Tenritatta (Raja Bone XV) boleh jadi merupakan asas yang sudah dipengaruhi oleh al-Qur'an.Dikatakan demikian, dalam riwayat sejarah, bahwa ketika La Tenritatta telah diangkat menjadi Raja Bone XV (1667-1969 M.) tepatnya saat beliau memotong rambutnya (Petta Malampe'e Gemme'na/orang yang berambut panjang), memberikan nasihat ataukah sebuah ultimatum; "namoni pakkogi atuongetta, namoni bolata awo aja mallupaiwi mabbu langkara,", yang berarti walau bagaimanapun kehidupan kalian, rumah kalian

\footnotetext{
${ }^{10}$ Lihat Muhammad Bahar Akkase Teng, "Falsafah Hidup Orang Bugis (Studi Tentang Pappaseng Kajaolaliddong di Kabupaten Bone)", Disertasi (Makassar: PPs UIN Alauddin, 2019), h. 106.
} 
terbuat dari bambu yang megah, akan tetapi jangan lupa membangun "langkara".Yang dimaksud langkara' adalah surau atau masjid. Melihat dari konteksnya dapat diasumsikan bahwa walaupun La Tenritatta Arung Palakka sebagai Raja dan Bugis Bone kala itu sudah terkenal eksistensi, kearifan dan budayanya, namun mampu memberikan gambaran kepada masyarakat bahwa pada esensinya Islam itu hal yang harus diperhatikan.

Mattulu tellue tidak hanya sebagai prinsip Bugis Bone sebagai moto hidup yang menyelaraskan konsep dan nilai ajarannya ke dalam alam pikiran budayanya, namun ia juga sejalan dengan tradisi keintelektualan al-Qur'an.Dalam al-Qur'an, ayat yang membicarakan mengenai perilaku menolong dan kerja sama sebagaimana yang dikandung dari prinsip mattulu telllue tersebut sangat beragam, baik it u yang menggambarkan makna secara tersurat maupun tersirat.

\section{Tolong-menolong dan Kerja Sama dalam al-Qur'an}

Di antara ragam redaksi yang digunakan al-Qur'an dalam menggambarkan makna representatif secara langsung dari tolongmenolong dan kerja sama yakni kata ta'âwun (تعاون) dan kata naṣr (نصر). ${ }^{11}$ Selain itu, kata kunci lain yang sederevasi dengan makna tolong-menolong adalah kata $z \operatorname{ahr}$ (ظهر) yang dapat berarti bantu. ${ }^{12}$

a. Kata Ta'āwun

Kata ta'ấwun (تعاون) berasal dari kata عون yang dalam alQur'an disebutkan sembilan kali dengan berbagai bentuknya sedangkan pada kata تعاون disebutkandua kali dalam satu kalimat atau dalam satu ayat, yakni terdapat dalam QS Al-Māidah/5: $2^{13}$ sebagaimana firman-Nya

الِقوَ......

\footnotetext{
${ }^{11}$ Ahmad Warson Munawwir, Al-Munawwir: Kamus Arab-Indonesia Terlengkap (Cet. XXV; Surabaya: Pustaka Progressif, 2002), h. 1424.

${ }^{12}$ Pengertian ini dapat ditemukan dalam Tafsìr al-Qur'ān al-'Az̄im (Tafsìr alJalālain) yang nantinya akan dibahas pada poin selanjutnya.

${ }^{13}$ Muhammad Fū'ād 'Abdul Bāqī, al-Mu'jam al-Mufahras li al-Fāz al-Qur'ān alKarīm (Indonesia: Maktabah Daḥlān, [t.th.]), h. 627-628.
} 
Terjemahnya: Dan tolong menolonglah kamu dalam (mengerjakan) kebajikan dan takwa, dan jangan tolong-menolong dalam berbuat dosa dan permusuhan ... ${ }^{14}$

Kata تعاونوا adalah dari pokok kata (maṣdar) mu'ā wanah yang berarti tolong-menolong, bantu-membantu. Diperintahkannya hidup tolong-menolong dalam membina البر yaitu segala ragam maksud yang baik dan didasarkan atas التقوى yaitu dengan mempererat hubungan dengan Allah swt. ${ }^{15}$ Kata التقوى dan البرى demiliki hubungan yang sangat erat, karena masing-masing menjadi bagian dari bagian yang lainnya. Kata البرsecara sederhana bermakna kebaikan, yaitu kebaikan dari segala aspek, mencakup segala macam dan ragamnya yang telah dipaparkan oleh syariat.

Dalam Kamus Besar Bahasa Indonesia, kebaikan dari segala aspek itu adalah sebuah kebajikan. ${ }^{16}$ Dalam artian kebajikan bagian dari kebaikan namun kebaikan belum masuk dalam kebajikaan. ${ }^{17}$ Dalam Wikipedia, dikemukakan bahwa "Kebajikan adalah kesempurnaan moral, yaitu suatu perilaku atau kualitas yang memenuhi kebaikan moral sebagai pondasi prinsip dan moral kebaikan."18

Oleh karena itu, kebajikan adalah suatu perbuatan, tindakan, kesadaran dan tenggang rasa dari seseorang terhadap orang lain. Perbedaan dari keduanya, kebajikan seseorang tidak terukur oleh batasan-batasan antar-makhluk hidup sedangkan kebaikan masih terbatas oleh pengenalan antara seseorang dengan orang lain maupun makhluk hidup yang lain. Karenanya, dapat pula diketahui bahwa

\footnotetext{
${ }^{14}$ Departemen Agama RI, Al-Qur'an dan Tafsirnya, jil. II (Cet. III; Jakarta: Departemen Agama RI, 2009), h. 349.

${ }^{15}$ Abdulmalik Abdulkarim Amrullah, Tafsir Al-Azhar,jil. III (Cet. VII; Singapura: Kerjaya Print Pte Ltd, 2007), h. 1601.

${ }^{16}$ Kebajikan $n$ kebaikan, perbuatan baik, jasa,sesuatu yg mendatangkan kebaikan maupun untung. Lihat Departemen Pendidikan Nasional, Kamus Besar Bahasa Indonesia(Jakarta: Pusat Bahasa Departemen Pendidikan Nasional, 2008), h. 658.

${ }^{17}$ Kebaikan $n$ 1) Sifat-sifat baik; perbuatan baik; 2) Kegunaan; 3) Sifat manusia yang dianggap baik menurut sistem norma dan pandangan umum yang berlaku. Lihat Departemen Pendidikan Nasional, Kamus Besar Bahasa Indonesia,h. 121.

${ }^{18}$ Lihat "Kebajikan", Wikipedia. http://id.m.wikipedia.org/wiki/Kebajikan (27 Juni 2019).
} 
keimanan dan segenap cabangnya demikian pula ketakwaan adalah bagian dari al-bir yang mencakup seluruh unsur agama Islam baik itu prinsip-prinsip keimanan dan penegakan syariat yang kedua prinsip itu adalah buah bentuk ketakwaan. Hal ini diterangkan oleh Allah dalam QS Al-Baqarah/2: 177.

Adapun kata العدوان الإثمdan البر sebagaimana halnya antara dan التقوى , terikat pada hubungan yang kuat bahwa masing-masing kata itu mengandung pengertian kata lainnya.Setiap dosa (الإثم) merupakan bentuk عدوان (tindakan melampaui batas) terhadap ketentuan Allah swt. yang berupa perintah atau larangan. Dan setiap tindakan ' $u d w \bar{a} n$, pelakunya telah berdosa. Namun apabila keduanya disebut secara bersamaan, maka masing-masing kata memiliki pengertian yang berbeda dengan yang lainnya.Al-Ithmu (dosa) berkaitan dengan perbuatan-perbuatan yang hukumnya haram. Misalnya, berdusta, zina, mencuri, minum khamar dan lainnya. Contoh-contoh ini merupakan perbuatan yang pada asal hukumnya haram. Adapun dengan al-' $u d w \bar{a} n$, kata ini lebih mengarah pada suatu pengharaman yang disebabkan oleh tindakan yang melampaui batas.

Pada ayat tersebut, Allah swt. telah memerintahkan hambaNya yang beriman untuk saling membantu dalam perbuatan baik dan meninggalkan kemungkaran yang merupakan ketakwaan. Dan Allah swt. melarang untuk saling mendukung kebatilan dan bekerjasama dalam perbuatan dosa dan perkara haram.

Al-Māwardì mengemukakan bahwa Allah swt. menganjurkan untuk saling menolong dalam kebaikan dengan beriringan dengan ketakwaan kepada-Nya, sebab dalam ketakwaan, terkandung rida Allah swt. Sementara saat berbuat baik, orang-orang akan menyukai (meridai)nya pula. Maka siapa saja yang dapat memadukan antara rida Allah dan rida manusia, sungguh kebahagiaannya telah sempurna dan kenikmatan baginya sudah melimpah. ${ }^{19}$

Menurut al-Marāghi, perintah tolong-menolong dalam mengerjakan kebaikan dan takwa adalah termasuk pokok-pokok

\footnotetext{
${ }^{19}$ Lihat Syaikh Imām al-Qurțūbi, al-Jāmi ${ }^{`}$ li Ahkām al-Qur'ān, terj. Ahmad Khotib, Tafsir Al Qurthubi, jil. VI (Cet. I; Jakarta: Pustaka Azzam, 2008), h. 115.
} 
petunjuk sosial dalam al-Qur'an. Karena ia mewajibkan kepada manusia agar saling memberi bantuan satu sama lain dalam mengerjakan apa saja yang berupa bagi umat manusia, baik pribadi maupun kelompok, baik dalam perkara agama maupun dunia, juga dalam melakukan setiap perbuatan takwa yang dengan itu mereka mencegah terjadinya kerusakan dan bahaya yang mengancam keselamatan mereka. ${ }^{20}$

Quraish Shihab mengemukakan bahwa apa yang disampaikan al-Marāghì di atas,merupakan prinsip dasar dalam menjalani kerjasama dengan siapapun. Karena ia mewajibkan kepada manusia agar saling memberi bantuan satu sama lain dalam mengerjakan apa saja yang berupa bagi umat manusia, baik pribadi maupun kelompok, baik dalam perkara agama maupun dunia, juga dalam melakukan setiap perbuatan takwa yang dengan itu mereka mencegah terjadinya kerusakan dan bahaya yang mengancam keselamatan mereka. ${ }^{21}$

Dalam al-Qur'an terdapat banyak kisah yang dapat diambil pelajaran terkait hal ini, di antaranya seperti kisah tentang serombongan lebah yang saling menolong dengan teliti lagi cermat dalam menunaikan kewajibannya, mengatur rumahnya dan memakmurkan sarangnya, supaya memungkinkan mereka untuk menunaikan tugas-tugasnya dalam memproduksi minuman, sebagaimana yang terdapat dalam QS Al-Nahl/16: 69. Terdapat pula kisah teladan baik yang dapat diperoleh dari kepribadian para nabi dan rasul yang telah Allah pilih untuk menyampaikan risalah-Nya dan diberikan kelebihan kepada mereka atas manusia lainnya. Seperti di

\footnotetext{
${ }^{20}$ Lihat Aḥmad Mușțafā al-Marāghì, Tafs̄̄r al-Marāghī, terj. Bahrun Abubakar, et al., Terjemah Tafsir al-Maraghi, jil. VI (Cet. I; Semarang: Tohaputra, 1987),h. 81.Ibn Khuwaizimandad mengemukakan, tolong-menolong dalam mengerjakan kebajikan dan takwa dapat dilakukan dengan berbagai cara. Wajib bagi seorang alim (berilmu) untuk menolong dengan ilmunya dengan cara mengajarkannya. Orang yang kaya wajib menolong mereka dengan hartanya. Adapun seorang pemberani, wajib memberikan pertolongan di jalan Allah dengan keberaniannya. Dalam hal ini, kaum muslim hendak saling membantu, bahu-membahu layaknya tangan yang satu. Lihat Syaikh Imām al-Qurțūbi, al-Jāmi` li Ahkām al-Qur'ān, jil. VI,h. 115-116.

${ }^{21}$ Lihat Aḥmad Mușțafā al-Marāghī, jil.VI, Tafs̄ir al-Marāghī, h. 81.
} 
antaranya Nabiyullāh Mūsā a.s. yang diberikan keistimewaan berupa kesempatan untuk berbicara langsung dengan Allah swt. ketika ia diperintahkan olehnya untuk pergi menemui Fir'aun dan menyampaikan risalah-Nya, namun yang dilakukan Mūsāadalah memohon kepada Allah untuk melapangkan dadanya, memudahkan urusannya dan menjadikan saudaranya yang bernama Hārūn sebagai sekutu yang dapat menolongnya untuk menegakkan risalah-Nya itu, sebagaimana yang diabadikan Allah dalam QS Țāhā/20: 25-32.

Dengan demikian, dapat disimpulkan bahwa manusia yang merupakan junjungan (penguasa) dari segala makhluk hidup diwajibkan untuk dapat saling tolong-menolong secara lebih kuat dan mendalam, karena tolong-menolong itu lebih baik bagi orang yang mengetahui bahwa kebersamaan jauh kebih baik daripada memisahkan diri. Selain itu, tolong-menolong juga lebih bermanfaat daripada perpecahan individu, mengingat karakter kehidupan ini menunjukkan adanya perbedaan tingkatan antara manusia dalam bakat dan kemampuan, usaha dan kekuatan, maka di antara mereka terdapat orang yang kuat dan lemah, yang sehat dan sakit, yang mampu dan tidak, sehingga apabila seluruhnya dapat saling menolong, maka kebutuhan itu akan terpenuhi dan kerancuan akan sirna.

Dalam pappaseng (wasiat) Bugis Bone sebagaimana yang pernah diungkapkan Kajao Laliddong dari esensi persatuan di atas ia mengibaratkan sebuah lidi, dengan mengatakan: "Seddi adidi keminang merenni, narekko maegani sipulung, de' nariulle poloi, tenripoadani narekko tau maega masseddi" ${ }^{22}$ dalam terjemahan bebas bahwa satu lidi terlampau kecil, namun jika terikat dalam jumlah yang banyak maka tidak dapat dipatahkan, terlebih-lebih jikalau tersebut diumpamakan sekelompok orang yang bersatu.

\footnotetext{
${ }^{22}$ Lihat Dinas Kebudayaan dan Pariwisata Kabupaten Bone, Sejarah Bone, h. 35.
} 


\section{b. Kata Nașr}

Kata nạsr (نصر) dalam al-Qur'an dengan berbagai bentuknya disebutkan sebanyak 62 kali. $^{23}$ Salah satu firman-Nya yakni terdapat dalam QS Al-Ṣāff/61: 14

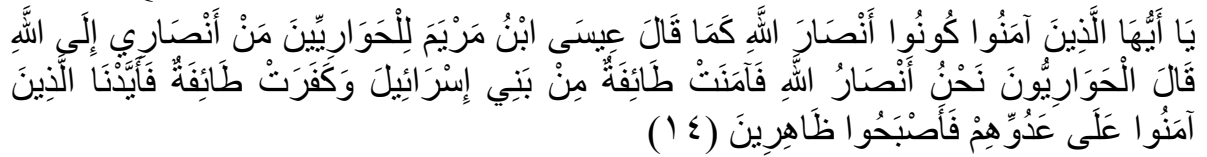

Terjemahnya: Hai orang-orang yang beriman, jadilah kamu penolong (agama) Allah sebagaimana 'İsā Ibn Maryam telah berkata kepada pengikut-pengikutnya yang setia: "Siapakah yang akan menjadi penolong-penolongku (untuk menegakkan agama) Allah?” Pengikutpengikut yang setia itu berkata: "Kamilah penolong-penolong agama Allah", lalu segolongan dari Bani Israil beriman dan segolongan lain kafir; maka Kami berikan kekuatan kepada orang-orang yang beriman terhadap musuh-musuh mereka, lalu mereka menjadi orang-orang yang menang.

Pada firman Allah, yā ayyuhallażīna āmanū kūmū anșārallāh (Hai orang-orang yang beriman, jadilah kamu penolong Allah) ${ }^{24}$ sebagaimana ketika 'Īsā a.s. berkata kepada kaum Hawari, man anșān $\bar{n}$ ilallāh (siapakah yang akan menjadi penolong-penolongku [untuk menegakkan agama] Allah?) ${ }^{25}$

\footnotetext{
${ }^{23}$ Muhammad Fū'ād 'Abdul Bāqī, al-Mu'jam al-Mufahras li al-Fāz al-Qur'ān al$\operatorname{Kan̄m}$ ([t.c.]; Indonesia: Maktabah Daḥlān, [t.th.]), h. 874-876.

${ }^{24}$ Terdapat perbedaan bacaan (qirā'ah) dikalangan ulama.Mayoritas ahli qirā'ah Madinah dan Basrah membacanya kunū anșārā lillāh, sedangkan ahli qirā 'ah Kufah membacanya dalam bentuk ị̣̂̂ fah yakni kūmu anșārallāh.Perbedaan dari bacaan ini menurut al-Ṭabarī tidak ada masalah, keduanya benar dan maknanya pun șah̄hh.Lihat Abū Ja'far Muhammad Ibn Jarīr al-Ṭabarī, Jāmi' al-Bayān 'anTa'wīl Ayi al-Qur'ān, terj. Akhmad Afandi, Tafsir ath-Thabari, jil. XXV(Cet. I; Jakarta: Pustaka Azzam, 2008), h. 23.

${ }^{25}$ Quraish Shihab menjelaskan, ayat 9 yang lalu menyebutkan bahwa Allah hendak memenangkan agama-Nya dan menyempurnakan cahaya-Nya, selanjutnya pada ayat 10 dan 11 mengisyaratkan bahwa kehendak tersebut Allah wujudkan melalui jihad orang-orang beriman, kemudian disusul oleh ayat 12 dan 13 dengan uraian tentang ganjaran yang disiapkan Allah kepada mereka yang berjihad di jalan Allah. Setelah penjelasan-penjelasan tersebut kini Allah mengundang orang-orang beriman untuk berjuang menolong agama Allah untuk membuktikan kebenaran iman mereka sekaligus guna terlaksananya kehendak-Nya itu. Lihat M. Quraish Shihab, Tafsir
} 
Pada esensinya Allah memang tidak membutuhkan petolongan, namun ungkapan yang seperti ini adalah guna untuk membangkitkan semangat orang-orang mukmin supaya lebih mendekatkat diri kepada Allah. Orang yang beriman kepada-Nya mesti tidaklah berfikir bahwa Allah memerlukan bantuan, namun yang harus digarisbawahi adalah menolong agama-Nya. Karena bagaiamanapun situasi dan kondisinya kebenaran yang diwahyukan Allah perlu diperjuangkan dan dipertahankan, karenanya orang yang menyediakan diri menolong dan membela agama Allah itu disamping sebagai wujud iman kepada-Nya juga diberi tata kehormatan oleh Allah sendiri, yaitu golongan anșārullāh. ${ }^{26}$

Kisah Nabi 'Īsā a.s. dan kaum hawāriyyūn tersebut, merupakan hal yang serupa yang dilakukan oleh Nabi Muhammad saw. kepada orang-orang yang mengaku beriman yang kemudian datang menemui beliau secara diam-diam di Yastrib dalam pertemuan di Aqabah-Mina. Beliau berkata; "Siapakah kiranya yang sudi membelaku, membantu dan menerima aku menumpang, sehingga aku dapat menyampaikan risalah Tuhanku, sedangkan kaum Quraisy selalu saja menghalang-halangiku?" Lalu orang-orang yang datang itu dari suku 'Aus dan Khazraj menyediakan diri. ${ }^{27}$

Mereka sediakan harta benda, jiwa, raga dan tenaga untuk membela dan membantu Nabi Muhammad saw. bahkan mereka mempersilahkannya pindah ke negeri mereka, al-Madinah alMunawwarah bahkan ia sampai menyebutnya Madinah alNabissebagai pusat perjuangan Islam. Hingga mereka (Aus dan Khazraj) mendapat nama kemuliaan yaitu golongan al-Anșār. ${ }^{28}$

Al-Mishbāh: Pesan, Kesan dan Keserasian Al-Qur'an, vol. XIV(Cet. I; Ciputat: Lentera Hati, 2001), h. 209.

${ }^{26}$ Haji Abdulmalik Abdulkarim Amrullah, Tafsir Al-Azhar,jil. IX (Cet. VII; Singapura: Kerjaya Print Pte Ltd, 2007), h. 7350, M. Quraish Shihab, Tafsir AlMishbāh: Pesan, Kesan dan Keserasian Al-Qur'an, vol. XIV,h. 210, juga Syaikh Abū Bakar Jabīr al-Jazairī, Aisar al-Tafăsir li al-Kalāmi al-Aliyyi al-Kabìr, terj. M. Azhari Hatim dan Abdurrahim Mukti, Tafsir Al-Qur'an Al-Aisar, jil. II(Cet. II; Jakarta: Darus Sunnah, 2011), h. 429.

${ }^{27}$ Abdulmalik Abdulkarim Amrullah, Tafsir Al-Azhar,jil. IX, h. 7351.

${ }^{28}$ Abdulmalik Abdulkarim Amrullah, Tafsir Al-Azhar,jil. IX, h. 7351. 
Orang-orang yang menyediakan diri jadi pembantu-pembantu Allah dan menyatakan kesanggupannya kepada Nabi 'İsā a.s. disebut golongan Hawān̄, maka pada kaum Nabi Muhammad saw. disebut golongan al-Anșār. Anșar sebagai timbalan dari kaum Muḥājirīn, yaitu orang-orang yang hijrah bersama Nabi saw., dari Mekah ke Madinah. Di dalam al-Qur'an tepatnya dalam QS Al-Taubah/9, nama al-Anșār disebut dua kali yang berjinjingan dengan al-Muhājirīn, yaitu pada ayat ke-100 dan 117.

Pada firman Allah, fa'āmanat țà'ifah min Bañ Isrā ‘̂l wa kafarat țà'ifah (lalu segolongan dari Bani Israil beriman dan segolongan [yang lain] kafir). Dijelaskan bahwa ketika Nabi 'İsā telah menyampaikan risalah Allah kepada kaumnya, ia mendapat dukungan dari kaum Hawari, maka segolongan dari kaum Bani Israil ada yang mendapat hidayah, dan segolongan yang lain sesat hingga kemudian menyimpang dari apa yang disampaikan 'İsā kepada mereka. Bahkan mereka mengingkari kenabiannya dan menuduh 'Īsā sebagai seorang anak zina yang dilahirkan karena perzinahan ibunya dengan seorang laki-laki, ada pula segolongan dari dari para pengikutnya yang berpendapat ekstrim hingga mereka meninggikannya lebih dari apa yang diberikan oleh Allah kepadanya, yaitu kenabian 'Īsā a.s. Hingga akhirnya mereka berpecah belah dalam beberapa aliran dan sekte. Di antara mereka ada yang beranggapan bahwa 'Īsā adalah anak Allah, yang lainnya mengatakan dia adalah salah satu dari tiga, yaitu Tuhan ayah, Tuhan anak dan Rūh al-Qudūs. Ada pula yang beranggapan bahwa 'İsā-lah Tuhan. Rincian mengenai hal ini telah diterangkan dalam QS Al-Nisā'/4. Bani Israil pada masa ini terpecah menjadi dua golongan, golongan pertama beriman dan membenarkan risalah 'Īsā dan golongan kedua kafir dan mendustakan Nabi 'Īsā a.s. ${ }^{29}$

Sebagaimana kandungan dari firman Allah, al-lażīna àman̄' 'alā 'uduwwihim fa aṣbahūżăhin̄n (maka Kami berikan

\footnotetext{
${ }^{29}$ Syaikh Muḥammad 'Ālī'Al-Șābūn̄̄, Șafwah al-Tafāsīr, terj. KH. Yasin, Shafwatut Tafasir: Tafsir-tafsir Pilihan, jil. II (Cet. I; Jakarta: Pustaka Al-Kausar, 2011), h. 338. Serta Aḥmad Muṭafa al-Marāghī, Tafs̄ir al-Marāghī, terj. Bahrun Abubakar, et. al., Terjemah Tafsir al-Maragi, jil. XXVIII (Cet. II; Semarang: CV. Toha Putra, 1993), h. 147-148.
} 
kekuatan kepada orang-orang yang beriman terhadap musuh-musuh mereka, lalu mereka menjadi orang-orang yang menang), yaitu dengan mengutus dan memenangkan Nabi Muhammad saw. melawan agama mereka yang kafir, dan mereka menjadi pemenangnya. ${ }^{30}$

Kemenangan tersebut ditandai dengan risalah tauhid yang dibawa oleh Nabi Muhammad yang mengalahkan paham dan sektesekte Nasrani, bahwa Nabi 'İsā bukanlah anak zina, anak Tuhan apalagi sampai dikatakan ia adalah Tuhan, melainkan ia adalah seorang hamba yang juga diutus oleh Allah swt. dalam menegakkan agama-Nya. Dalam sejarah, tercatat begitu banyak para tokoh jazirah Arab, baik kalangan bangsawan, agamais dan lainnya yang mengakui kebenaran yang disampaikan oleh Nabi Muhammad hingga menyatakan diri masuk Islam, di antaranya seperti Najasyi-Raja Habsyi, Adi Ibn Hatim dan saudara perempuannya, yaitu puteraputera dari Hatim al-Ṭāì seorang dermawan masyhur, demikian juga Tamīm al-Dārī dan beberapa pendeta Habsyi yang datang sendiri menghadap Rasulullah saw. di Madinah. Sehingga benarlah firman Allah fa aṣbahūzāahin̄n (lalu mereka menjadi orang-orang yang menang). ${ }^{31}$

Oleh karena itu, ketika Allah swt. mengutus Nabi Muhamad saw. maka pada saat itu, turun pulalah pembenaran dari mereka yang percaya kepada Nabi 'Îsā a.s. yang menjadi hujjah atas mereka yang beriman. $^{32}$

Firman Allah dalam ayat ini, telah mengisyaratkan bahwa Allah swt. memberi kemenangan kepada sahabat-sahabat Nabi 'Īsā a.s. Boleh jadi kemenangan itu mereka peroleh dimasa hidup mereka, lalu setelah kematiannya tidak ada lagi yang gigih memperjuangkan ajaran 'İsā a.s., nanti setelah 200 tahun lebih barulah mereka bangkit kembali.

\footnotetext{
${ }^{30}$ Abū Ja'far Muhammad Ibn Jarīr al-Ṭabarī, Jāmi' al-Bayān an Ta’w̄̄l Āyi alQur'ān, terj. Akhmad Afandi, Tafsir Ath-Thabari,jil XXV (Cet. I; Jakarta: Pustaka Azzam, 2008), h. 28.

${ }^{31}$ Abdulmalik Abdulkarim Amrullah, Tafsir Al-Azhar,jil. IX, h. 7352.

${ }^{32} \mathrm{Abū} \mathrm{Ja}^{\prime}$ far Muhammad Ibn Jarīr al-Ṭabarī, Jāmi' al-Bayān 'an Ta'wīl $\bar{A} y i$ alQur'ān, jil XXV,h. 29-30.
} 
Surah ini dibuka dengan pemberitahuan bahwa semua makhluk di langit dan di bumi bertasbih kepada Allah swt. dimana pada awal surah ini memberi pesan bahwa seyogyanya orang-orang mukmin tidaklah pantas mengatakan sesuatu namun tidak dilaksanakan, padahal Allah menyukai mereka yang bersatu padu dalam berjihad menegakkan agama Allah, sebagai mana pada ayat ini sebagai ayat penutup dari QS Al-Șāff/61, berbicara tentang jihad sambil memberi contoh tentang pengikut-pengikut 'Īsā a.s. yang setia kepadanya, sebagaimana ucapan mereka yang dibuktikan dengan perbuatannya. $^{33}$

Persesuain antara perkataan dan perbuatan hanya timbul dari jiwa yang terlatih jujur dan ikhlas. Dengan pendirian yang demikian orang selalu berusaha mempertinggi mutu dirinya. Kejujuran adalah hasil dari iman, dimana pada setiap diri umat Islam melatih dan membersihkan batinnya dengan sifat tersebut. Orang yang mengusahan dirinya agar lebih bersih dan lebih berguna dia akan masuk dalam barisan, yaitu barisan kaum mu'minīn, yang menyatukan tenaga dibawah pimpinan seorang imam. Karena Islam tidaklah menganjurkan untuk berpecah belah, karena perpecahan itu akan menghilangkan kekuatan.

Sebagaimana yang disabdakan Rasulullah Muhammad saw. tentang anjuran untuk bekerja sama dan tidak saling berselisih.

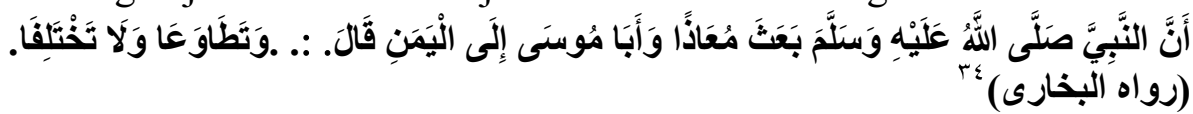

Artinya: Bahwa Nabi saw. mengutus Mu'āż dan Abū Mūsā ke negeri Yaman dan Beliau berpesan: . . . bekerja samalah kalian dan jangan berselisih".(HR. Al-Bukhārī)

Selain itu terdapat pulan anjuran Rasulullah saw. yang menekankan untuk saling menolong. Di zaman jahiliah ada semboyan yang sangat populer yaitu

\footnotetext{
${ }^{33}$ M. Quraish Shihab, Tafsir Al-Mishbāh: Pesan, Kesan dan Keserasian Al-Qur'an, vol. XIV, h. 211.

${ }^{34}$ Muhammad Ibn Ismā‘̄il Ibn Ibrāhīm Ibn al-Mugīrah Ibn Bardiżbah, Kitab Bukhari, dalam Ensiklopedia Hadis [CD ROM], PT Kreasi Riset Informatika Sistem Solusi (Keriss), (t.th.), hadis no. 2811.
} 
Artinya:Tolonglah saudaramu, baik itu menganiaya maupun dianiaya.

Semboyan ini sudah menjadi simbol kebanggan jahiliah dan fanatisme kebangsaan, dimana tolong-menolong dalam perbuatan dosa dan pelanggaran lebih dekat dan lebih kuat daripada tolongmenolong dalam kebajikan dan takwa. Mereka juga biasa mengadakan janji setia untuk bahu-membahu dalam kebatilan demi menghadapi kebenaran, jarang sekali pada zaman jahiliah mengadakan janji setia dalam membela kebenaran. Beginilah tabiat lingkungan masyarakat yang tidak berhubungan dengan Allah, yaitu masyarakat yang tradisi dan akhlaknya tidak berpijak pada manhaj Allah swt. Semua itu mencerminkan prinsip jahiliah yang terkenal "Tolonglah saudaramu baik ia menganiaya ataupun dianiaya." Ini merupakan prinsip yang oleh penyair jahili dikemas dalam bentuk lain dengan mengatakan "Aku adalah seorang prajurit, jika engkau melanggar aku pun melanggar dan jika engkau lurus dalam peperangan, aku pun lurus." 36

Setelah Islam datang, semboyan itu tetap terpelihara hingga sekarang. Namun dikemas dalam bentuk yang berbeda, yang dulunya lebih dekat kepada kebatilan namun kemudian diubah menjadi suatu hal yang baik.Rasulullah Muhammad saw. bersabda

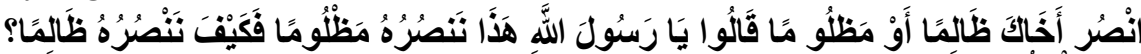

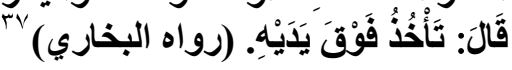

Artinya: Bantulah saudaramu, baik dalam keadaan sedang berbuat zalim atau sedang teraniaya. Ada yang bertanya: "Wahai Rasulullah, kami akan menolong orang yang teraniaya. Bagaimana menolong orang yang sedang berbuat zalim?" Beliau menjawab: "Dengan menghalanginya melakukan kezaliman. Itulah bentuk bantuanmu kepadanya." (HR. Al-Bukhārī).

\footnotetext{
${ }^{35}$ Sayyid Quṭb, FīZilāl al-Qur'ān, terj. As'ad Yasin, Tafsir Fi Zhilalil Qur'an: Di Bawah Naungan Al-Qur'an, jil. V (Cet. I; Jakarta: Gema Insani Press, 2002), h. 255. ${ }^{36}$ Sayyid Quṭb, FïZilāl al-Qur'ān, jil. V,h. 255-256.

${ }^{37}$ Ibn Kathīr, Muktașar Tafsìr Ibn Kathīr, terj. Salim Bahreisy dan Said Bahreisy,Terjemah Singkat Tafsir Ibnu Katsier,jil. III (Cet. I; Kuala Lumpur: Victory Agencie, 1988),h. 8.
} 
Oleh karena itu, hendaknya seorang muslim dapat menolong sebagian yang lain dalam suatu perbuatan, yang mengandung kebajikan dan ketakwaan, juga berlaku pada penegakan syariat Allah yang harus ditegakkan secara bersama-sama pula.

\section{c. Kata Zahr}

Zahr (ظهر) dalam bahasa Arab pada dasarnya berarti tampak, lahir, jelas dan terang. ${ }^{38}$ Namun dalam al-Qur'an di samping ia menunjukkan arti tampak, juga kadang kala menggunakan kata zahr untuk menunjukkan arti bantu. Sebagaimana firman Allah dalam QS Al-Baqarah/2: 85

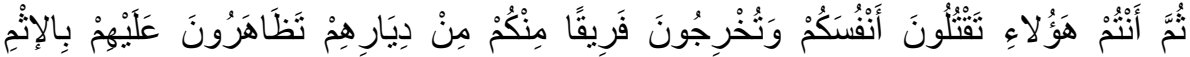

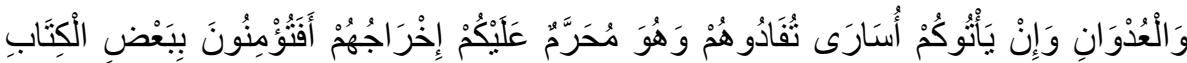

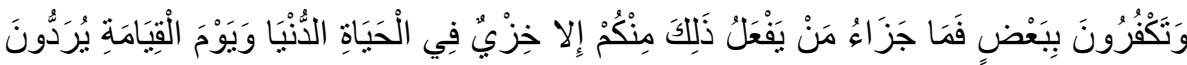

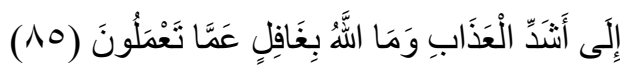

Terjemahnya: Kemudian kamu (Bani Israil) membunuh dirimu (saudaramu sebangsa) dan mengusir segolongan daripada kamu dari kampung halamannya, kamu bantu membantu terhadap mereka dengan membuat dosa dan permusuhan; tetapi jika mereka datang kepadamu sebagai tawanan, kamu tebus mereka, padahal mengusir mereka itu (juga) terlarang bagimu. Apakah kamu beriman kepada sebahagian al-Kitab (Taurat) dan ingkar terhadap sebahagian yang lain? Tiadalah balasan bagi orang yang berbuat demikian daripadamu, melainkan kenistaan dalam kehidupan dunia, dan pada hari kiamat mereka dikembalikan kepada siksa yang sangat berat. Allah tidak lengah dari apa yang kamu perbuat. ${ }^{39}$

Pada ayat inimerupakan sambungan dari ayat sebelumnya (QS Al-Baqarah/2: 84) yang menjelaskan perbuatan buruk Bani Israil yang telah memutarbalikkan isi Taurat dan mengakibatkan kerusakan agama mereka. Dan dalam ayat ini dijelaskan lagi kejahatan-

\footnotetext{
${ }^{38}$ Lihat Ahmad Warson Munawwir, Al-Munawwir: Kamus Arab-Indonesia Terlengkap, h. 883.

${ }^{39}$ Departemen Agama RI, Al-Qur'an dan Tafsirnya, jil. I (Cet. III; Jakarta: Departemen Agama RI, 2009), h. 140.
} 
kejahatan mereka yang lain yaitu meninggalkan kewajiban agama dan melakukan tindakan yang melanggar hukum.

Ayat summa antum hāulā'i (kemudian kamu [Bani Israi]), diartikan kalian atau mereka yang hadir yakni yang hidup pada zaman Nabi Muhammad saw. menyeru agama Islam, telah menyaksikan ikrar nenek moyangnya terhadap janji-janji mereka kepada Allah yang diserukan oleh Nabi Mūsā a.s. Namun, setelah pernjanjian tersebut dikukuhkan, mereka lantas merusaknya dengan tetap saling membunuh dan saling mengusir yang hingga sekarang (yakni masa Nabi Muhammad saw.) masih tetap seperti itu. Padahal kalian tahu bahwa perjanjian yang diikrarkan nenek moyang kalian tidak hanya berlaku bagi mereka, namun juga berlaku pada kalian. ${ }^{40}$

Pada ayat wa tukhrijūna fā̄qan minkum min diyārihim, tạāhanūna 'alaihim bi al-is̈mi wa al-'udwān (dan mengusir segolongan daripada kamu dari kampung halamannya, kamu bantu membantu terhadap mereka dengan membuat dosa dan permusuhan).

Ayat ini menjelaskan bahwa masing-masing kaum Yahudi tersebut dengan sekuat tenaga mendukung para sekutunya yang terdiri dari kabilah Arab, di samping memberikan pertolongan kepada mereka sepenuh hati, namun sebaliknya pula mereka juga memusuhi saudara-saudara mereka sendiri yang berpihak kepada masing-masing kabilah Arab yang berperang itu. Mereka membunuh, dan bagi pihak yang kalah hartanya dirampas dan diusir dari kediamannya. ${ }^{41}$

Dalam tafsir al-Kabīr yang dikutip al-Buruswi, ayat ini telah menunjukkan bahwa hal tersebut merupakan sebuah kezaliman yang haram untuk dilakukan, demikian pula halnya dengan menolong orang zalim dalam berbuat zalim. ${ }^{42}$

Ayat wa in ya'tūkum usārā tufädūhum wa huwa muḥarramun 'alaikum ikhrājuhum (tetapi jika mereka datang kepadamu sebagai

\footnotetext{
${ }^{40}$ Ahmmad Mușțafa al-Marāghī, Tafsīr al-Marāghī, terj. Bahrun Abubakar, et. al., Terjemah Tafsir al-Maraghi, jil. I (Cet. II; Semarang: CV. Toha Putra Semarang, 1992), h. 292.

${ }^{41}$ Aḥmad Muștafa al-Marāghì, Tafsīr al-Marāghī, jil.I, h. 292.

${ }^{42}$ Ismā̄îl Ḥaqqī al-Buruswi, Tafsìr Rūh al-Bayān, terj. Syihabuddin. Terjemah Tafsir Ruhul Bayan, jil. I(Cet. I; Bandung: CV. Diponegoro, 1995), h. 624.
} 
tawanan, kamu tebus mereka, padahal mengusir mereka itu [juga] terlarang bagimu). Maksudnya, sebagian bangsa Arab dan para sekutu yang terdiri dari kaum Yahudi, jika menahan kaum Yahudi lain yang menjadi musuh, mereka itu sudah saling sepakat untuk saling bertukar tawanan. Setiap kelompok kaum Yahudi selalu berusaha menebus saudara-saudaranya yang sebangsa Yahudi walau sebelumnya mereka bermusuhan. ${ }^{43}$

Dijelaskan bahwa hal yang tentu mengherankan ketika bangsa Arab bertanya kepada mereka tentang "Kenapa kamu perangi dan kamu tebus mereka". Ketika peperangan telah berhenti maka dari pihak Bani Quraizah menebus tawanan perang yang ada pada genggaman kekuasaan Bani Khazraj, padahal Quraizah dan Khazraj merupakan sekutu namun Quraizah menebus tawan perangnya sendiri. Begitu pula sebaliknya, dari pihak Bani Nadir menebus tawanan perangnya yang ditawan oleh Bani 'Aus sekutunya sendiri. Bagaimana mungkin mereka sendiri memeranginya, namun mereka sendiri pula menebusnya. Lantas mereka menjawab sebagaimana pada pendapat lain, "Kami diperintah Allah untuk menebus merekadan diharamkan bagi kami membunuh mereka, kami ikut perang karena kami malu kalau pendukung kami mengejek kami."44

Dalam ayat ini mempunyai deskripsi adanya tiga perkara yang telah diwajibkan atas mereka, yaitu

1) Diwajibkan atas mereka agar tidak menumpahkan darah satu sama lain

2) Sebagian mereka agar tidak saling mengusir satu sama lain.

3) Apabila mendapatkan tawanan di antara mereka, maka wajib at as mereka untuk menebusnya.

Namun mereka justru memilah dan hanya mengamalkan yang terakhir tersebut dan tidak mengamalkan dua hal yang sebelumnya.Ayat ini, menerangkan bahwa sesudah menerima janji yang kuat itu, mereka merusaknya dengan membunuh saudarasaudara mereka sendiri, mereka saling membunuh sebagaimana yang

\footnotetext{
${ }^{43}$ Aḥmad Mușțafa al-Marāghī, Tafs̄ì al-Marāghī, jil.I,h. 293.

${ }^{44}$ Ismā'‘̄l Haqqī al-Buruswi, Tafsìr Rūh al-Bayān, jil. I, h. 625.
} 
telah dilakukan oleh orang-orang terhadap mereka, sedangkan mereka mengaku bahwa janji Allah itu juga dikenakan pada mereka. ${ }^{45}$

Gambaran perilaku kaum Yahudi tersebut adalah sebuah kekufuran. Sebagaimana yang dikemukakan Muhammad Abduh, bahwa kedurhakaan mereka tersebut dinamai kekufuran, ungkapan tentang pelanggaran dan kemaksiatan dengan kata kufur berarti orang yang melakukan perbuatan tersebut tidak merasa menyesal sedikit pun. Hatinya tidak merasa sakit dan ia terus bersikap arogan, larangan-larangan Allah tidak dihiraukan dan mereka telah sampai pada derajat kafir kepada Allah swt. ${ }^{46}$

Pendapat Muhammad Abduh di atas, diperkuatnya dengan hadis Nabi Muhammad saw yang berbunyi

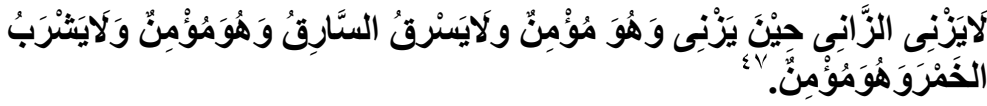

Artinya: Seseorang tidak bisa dikatakan beriman ketika ia melakukan perbuatan zina. Dan seseorang tidak bisa dikatakan beriman ketika ia sedang melakukan pencurian. Dan seseorang tidak bisa dikatakan beriman ketika ia sedang minum khamar.

Adapun menurut Quraish Shihab, kedurhakaan mereka tersebut dinamai kekufuran, kata kufur menurut Qurasih Shihab tidak selalu berarti keluar dari keimanan. Tidak melaksanakan perintah Allah juga dinamai kekufuran, bahkan yang tidak mensyukuri nikmat sekalipun, kikir dan tidak mau membatu terkadang dalam al-Qur'an menyebutnya suatu bentuk kekufuran. ${ }^{48}$ Olehnya kata syukur diperhadapkan dengan kufur sebagaimana yang terdapat dalam QS Ibrāhīm/14: 7

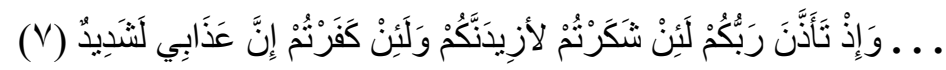

\footnotetext{
${ }^{45}$ Departemen Agama RI, Al-Qur'an dan Tafsirnya, jil. I, h. 144.

${ }^{46}$ Ahmmad Mușțafa al-Marāghi, Tafsìr al-Marāghī, jil. I, h. 294.

${ }^{47}$ Aḥmad Mușțafa al-Marāghì, Tafsìr al-Marā ghī, jil. I, h. 294.

${ }^{48}$ M. Quraish Shihab, Tafsir Al-Mishbāh: Pesan, Kesan dan Keserasian Al-Qur'an, vol. I, h. 243.
} 
Terjemahnya:. . . Sesungguhnya jika kamu bersyukur, pasti Kami akan menambah (nikmat) kepadamu, dan jika kamu mengingkari (nikmat-Ku), maka sesungguhnya azab-Ku sangat pedih. ${ }^{49}$

Lebih lanjut Quraish Shihab mengemukakan, mungkin juga kekufuran orang-orang Yahudi yang dimaksud oleh ayat ini adalah kekufuran dalam arti tidak mempercayai tuntunan-tuntunan ilahi tersebut. Karena kekufuran dapat saja terjadi walau seseorang percaya kepada Allah tetapi tidak mempercayai kewajiban-kewajiban yang telah ditetapkan-Nya. Kalau itu yang terjadi dan terus berlanjut, maka ia pasti tidak akan mendapat buah dari sikapnya itu keculai hanyala nista dalam kedupan dunia. ${ }^{50}$

Dari ketiga term yang telah dikemukakan di atas, mewakili dari beberapa rangkaian ayat al-Qur' an yang sederivasi dengan makna tolong-menolong, poin penting yang dikandung pada ketiga ayat tersebut bahwa perilaku menolong harus ada pada diri manusia, menolong pada ayat-ayat ini mencakup segala unsur kebaikan. Sebagaimana yang telah dijelaskan, hal ini merupakan prinsip dasar dalam menjalani kerjasama dengan siapapun. Karena ia mewajibkan kepada manusia agar saling memberi bantuan satu sama lain dalam mengerjakan berbagai hal. Termasuk pada dewasa ini, di antaranya membantu para ulama dalam menyebarkan dakwah demi terealisasinya amar ma' $n \bar{u} f$ nah̄ munkar di persada bumi ini.

Perilaku menolong pada ayat-ayat yang telah dijelaskan, menyangkut segala perbuatan yang berfaidah baik dalam bentuk fisik maupun nonfisik dalam segala keadaan apapun, mulai dari perbuatan yang terkecil seperti memberi senyuman, mengorbankan harta, bahkan jiwa dan raga, termasuk waktu, tenaga, pikiran dan sikapsikap yang memberikan kesan positif kepada mereka yang membutuhkan. Karena pada substansinya menolong adalah sebuah tindakan yang bertujuan semata-mata untuk meningkatkan

\footnotetext{
${ }^{49}$ Departemen Agama RI, Al-Qur'an dan Tafsirnya, jil. V (Cet. III; Jakarta: Departemen Agama RI, 2009), h. 127.

${ }^{50}$ M. Quraish Shihab, Tafsir Al-Mishbāh: Pesan, Kesan dan Keserasian Al-Qur'an, vol. I, h. 243.
} 
kesejahteraan orang yang membutuhkan tanpa mengharapkan balasan apapun dari orang tersebut.

\section{Model-model Perilaku Menolong dan Kerja Sama dalam al-Qur'an}

Model-model ini dapat diklasifikasikan atas tiga hal yaitu didasarkan pada sifat materi, paraktik dan immateri.

Pertama, dari segi materi melingkupi; donating (donasi/sumbangan) dan genereocity (berderma). Hal tersebut merupakan pemberian yang pada umunya dalam bentuk fisik/benda baik dilakukan oleh seorang diri maupun kelompok, seperti makanan, pakaian dan lainnya. Dalam Islam pemberian-pemberian ini dinamai zakat, infak dan atau sedekah.

Zakat diformulasikan sebagai harta yang wajib dikeluarkan oleh orang Islam yang telah mencapai syarat tertentu untuk kemudian mengeluarkan dan memberikannya kepada orang yang berhak menerimanya dengan syarat-syarat tertentu.Sedang infak adalah mengeluarkan sebagian dari harta atau pendapatan untuk suatu kepentingan yang diperintahkan. Zakat ada nisabnya, sedangkan infak dan sedekah tidak. Jika zakat harus diberikan kepada mustahiq $q^{51}$ tertentu, maka infak boleh diberikan kepada siapapun juga. Sementara sedekah sama dengan infak, termasuk dalam hukum dan ketentuan-ketentuannya. Hanya saja, infak berkaitan dengan materi, sedangkan sedekah lebih kepada materi maupun non-materi, seperti senyuman. $^{52}$

Oleh karena itu, tampak secara jelas akan pentingnya membelanjakan harta baik itu zakat, infak dan sedekah, yang karenanya dapat memperkokoh tali persaudaraan, meratakan cinta dan keselarasan dan mewujudkan kedamaian dan keteraturan. Terlebih lagi dalam zakat yang mesti dikeluarkan dengan tidak secara

\footnotetext{
${ }^{51}$ Terdapat delapan asnāf mustahiq; yang berhak menerima zakat, yaitu orang fakir (fuqarā), orang miskin(masākin), pengurus zakat ( 'àmi $\bar{\imath} n$ ), orang yang baru masuk Islam (mu'allaf), orang yang memerdekakan budak(quh̄buhumriqāa), orang berhutang ( $g \bar{a} r i m \bar{\imath} n)$, orang yang berjuang di jalan Allah (sabìlillāh), dan orang yang sedang dalam perjalanan (Ibn $s a b \bar{l})$. Kedelapankelompokinitermaktubdalam QS AlTaubah/9: 60 .

${ }^{52}$ Terdapat banyak dalil akan pentingnya membelanjakan harta, dua di antaranya terdapat pada QS Al-Baqarah/2: 165dan QS Al-Baqarah/2: 254.
} 
suka rela, akan tetapi ia merupakan suatu hak dan amanah terhadap harta yang harus dikeluarkan kepada kaum fakir dan miskin. ${ }^{53}$

Salah satu firman Allah yakni QS Al-Ma‘ārij/70: 24-25

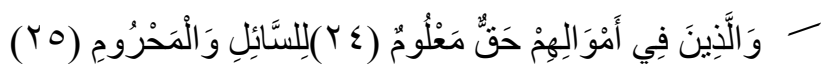

Terjemahnya: Dan orang-orang yang dalam hartanya tersedia bagian tertentu,bagi orang (miskin) yang meminta dan orang yang tidak mempunyai apa-apa (yang tidak mau meminta). ${ }^{54}$

Kedua, dari segi praktikal melingkupi; cooperating (kerjasama), helping (menolong) dan intervention in emergency (tindakan dalam keadaan darurat). Rasulullah Muhammad saw. telah memberikan teladan yang agung dalam tolong-menolong semacam ini.

Dalam sejarah Islam yang dilakukan kaum Anșār terhadap kaum Muhājirīn telah menjadi bukti terbesar tentang efektivitas tolong-menolong dan kerja samayang bersifat praktikal dalam naungan Islam.Di antara contohnya yaitu sebagaimana yang diriwayatkan oleh 'Abdurraḥmān Ibn 'Auf r.a. yang berkata, "Ketika kami memasuki Madinah, Rasulullah saw. mempersaudarakanku dengan Sa'ad Ibn al-Rabi' al-Anșāri. Lalu Sa'ad Ibn al-Rabi' r.a. berkata kepada 'Abdurraḥmān, "Sesungguhnya Aku adalah orang Anșār yang memiliki paling banyak harta, Aku akan membagikan hartaku menjadi dua bagian; milikku dan milikmu dan Aku memiliki dua isteri, lihatlah mana yang paling mengagumkanmu, maka Aku akan menceraikannya." Sehingga jika selesai iddahnya, kami dapat menikahinya."55

Ketiga, dari segi immaterial melingkupi; sharing (berbagi perasaan), caring (peduli), honesty (kejujuran) dan favor (kebaikan hati). Aspek-aspek ini adalah sebuah kerjasama antara nurani dan perasaan yang bertindak untuk meringankan kesulitan orang lain.

\footnotetext{
${ }^{53}$ Syaikh Muḥammad 'Abdul Ați Buhairi, Nadāat al-Raḥmān li Ahl al-Īmān, terj. Abdurrahman Kasdi dan Umma Farida (Cet. I; Jakarta: Pustaka Al-Kautsar, 2005),h. 377.

${ }^{54}$ Departemen Agama RI, Al-Qur'an dan Tafsirnya, jil. X, h. 334.

${ }^{55}$ Lihat Syaikh Muḥammad 'Abdul Ați Buhairi, Nadāat al-Raḥmān li Ahl al-Īmānn,h. 380 .
} 
Firman Allah dalam QS Al-Isrā': 24.

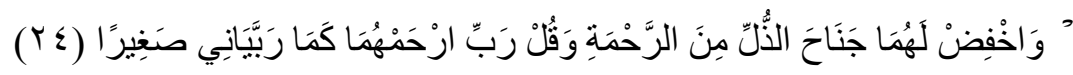

Terjemahnya: Dan rendahkanlah dirimu terhadap mereka berdua dengan penuh kesayangan dan ucapkanlah: "Wahai Tuhanku, kasihilah mereka keduanya, sebagaimana mereka berdua telah mendidik aku waktu kecil." ${ }^{56}$

Firman Allah dalam QS Al-Baqarah/2: 263

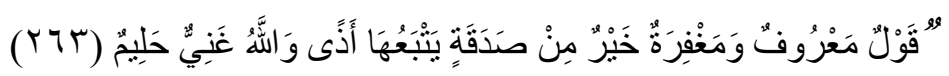

Terjemahnya: Perkataan yang baik dan pemberian maaflebih baik dari sedekah yang diiringi dengan sesuatu yang menyakitkan (perasaan si penerima). Allah Maha Kaya lagi Maha Penyantun. ${ }^{57}$

Orang yang demikian ini sangat disenangi oleh Allah bahkan Allah menjamin kehidupannya, sebagaimana sabda Rasulullah Muhammad saw.

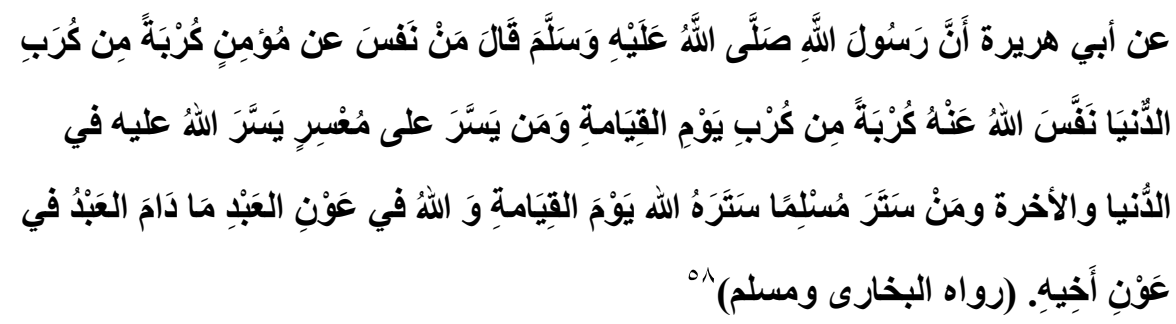

Artinya: Dari Abū Hurairah bahwa Rasulullah saw. bersabda: "Barangsiapa yang menghilangkan salah satu kesusahan dari sekian kesusahan dunia yang menimpa seorang mukmin, maka Allah akan menghilangkan salah satu kesusahan pada hari kiamat. Barangsiapa yang memberikan kemudahan kepada orang-orang yang ditimpa kesulitan, maka Allah akan memberikan kemudahan kepadanya di dunia dan di akhirat. Dan barangsiapa yang menutupi aib seorang muslim, maka Allah akan menutupi aibnya pada hari kiamat dan Allah selalu akan menolong hamba-Nya selama hamba itu mau menolong saudaranya." (HR Al-Bukhāri dan Muslim).

\footnotetext{
${ }^{56}$ Departemen Agama RI, Al-Qur'an dan Tafsirnya, jil. V, h. 458.

${ }^{57}$ Departemen Agama RI, Al-Qur'an dan Tafsirnya, jil. I, h. 391.

${ }^{58}$ Syaikh Muhammad 'Abdul Aṭi Buhairi, Nadāat al-Raḥmān li Ahl al-Īmānn,h. 381.
} 


\section{Epilog}

Adapun kesimpulan yang dapat ditarik dalam penelitian ini adalah sebagai berikut:

1. Mattulu tellue merupakan salah satu prinsip yang dilegitimasi dalam kehidupan sehari-hari. Mattulu tellue yang populer hingga sekarang adalah mattulu tellue yang pernah didiktumkan oleh La Tenritatta Arung Palakka (Raja Bone XV). Mattulu tellue dapat dimaknai "yang saling bertaut tiga menjadi satu kepaduan", adapun yang bertaut tiga itu adalah mali siparappe, rebba sipatokkong dan malilu sipakainge. Bentuk mattulu tellueini mengarah pada prinsip-prinsip tatanan adat orang Bugis Bone yang mengarah pada konsep tolong menolong dan gotong royong, merupakan pesan moral dari leluhur bukan saja sebagai hal yang prinsipil, namun juga moto dan menjadi falsafah hidup Bugis Bone yang mengharapkan adanya harapan untuk bersatu.

2. Nilai yang dikandung dari prinsip mattulu tellue tersebut adalah bagian dari konsep sosial, kaitannya dengan hubungan dengan sesama yaitu tolong-menolong dan kerja sama. Adapun wujud dari tolong-menolong dan gotong royong pada masyarakat Kabupaten Bone yaitu; 1) Dalam segi pertanian, masyarakat Bone dikenal istilah minawang yaitu sebuah corak hubungan asimetris (tidak seimbang) yang terjadi antara ajjoareng (pemilik tanah) dengan joa (pekerja). Hubungan minawang yang terjadi anatara ajjoareng dengan joa mengikuti pola hubungan patron-klien, ajooareng sebagai patron dan joa sebagai kliennya. Dengan demikian pola ini membentuk sebuah hubungan tolong-menolong dan gotong royong yang sangat khas serta saling menguntungkan kedua belah pihak, baik secara ekonomi, sosial maupun kultural. 2) Dalam halrumah tangga; contohnya dapat dilihat pada kegiatan mappatettongg bola (mendirikan/membangun rumah) dan mappalecce bola (memindahkan rumah)atau marakka bola (mengangkat rumah).

3) Dalam hal pesta atau hajatan, Bone sangat terkenal dengan 
pesta panen rayanya, digelar secara kegotongroyongan pada setiap tahunnya oleh beberapa desa di Kab. Bone.

3. Mattulu tellue tidak hanya sebagai prinsip suku Bugis Bone yang hidup dengan menyelaraskan konsep dan nilai ajarannya ke dalam alam pikiran budayanya, namun ia juga sejalan dengan tradisi keintelektualan al-Qur'an, yang telah menjadi bagian yang integral dari syariat Islam karena ia hadir dengan nilai keislaman sebagaimana yang termaktub dalam beberapa ayatayatal-Qur'an. Dalam hal tolong menolong di antaranya dapat ditemui dalam QS Al-Māidah/5: 2, QS Al-Șāff/61: 14, ataupun QS Al-Baqarah/2: 85, di mana ketiga dari ayat tersebut mewakili dari beberapa term tentang kata tolong-menolong dalam al-Qur'an. Sedangkan dalam hal kerja sama atau gotong royong salah satunya dapat ditemui dalam QS Al-Hasyr/59: 9 yang mengandung kisah tentang kaum Muhajirin dan Ansar yaitu masa ketika Rasulullah Muhammad saw hijrah bersama sahabat dari penduduk Mekah (Muhajirin) yang disambut hangat dengan penduduk Madinah (Ansar).

\section{Daftar Pustaka}

"Kebajikan", Wikipedia. http://id.m.wikipedia.org/wiki/Kebajikan (27 Juni 2019).

Abidin, Zainal. Filsafat Manusia: Memahami Manusia Melalui Filsafat. Cet. VIII; Bandung: PT Remaja Rosdakarya, 2017.

Amrullah, Abdulmalik Abdulkarim. Tafsir Al-Azhar, jil I. Cet. VII; Singapura: Kerjaya Print Pte Ltd, 2007.

Amrullah, Haji Abdulmalik Abdulkarim. Tafsir Al-Azhar,jil. III. Cet. VII; Singapura: Kerjaya Print Pte Ltd, 2007.

Amrullah, Haji Abdulmalik Abdulkarim. Tafsir Al-Azhar,jil. IX. Cet. VII; Singapura: Kerjaya Print Pte Ltd, 2007.

Bāqī, Muhammad Fū'ād 'Abdul. al-Mu'jam al-Mufahras li al-Fāz alQur'ān al-Kan̄m. Indonesia: Maktabah Daḥlān, (t.th.).

Bāqī, Muḥammad Fū'ād 'Abdul. Al-Mu'jam al-Mufahras li al-Fāz alQur'ān al-Kar̄mm. Indonesia: Maktabah Daḥlān, (t.th.).

Buhairi, Syaikh Muhammad 'Abdul Ați. Nadāat al-Rahmān li Ahl alImānn.Terj. Abdurrahman Kasdi dan Umma Farida. Cet. I; Jakarta: Pustaka Al-Kautsar, 2005. 
al-Buruswi, Ismā'îl Haqqī. Tafsìr Rūḥ al-Bayān. Terj. Syihabuddin. Terjemah Tafsir Ruhul Bayan, jil. I.Cet. I; Bandung: CV. Diponegoro, 1995.

Departemen Agama RI.Al-Qur'an dan Tafsirnya,jil. I. Cet. III; Jakarta: Departemen Agama RI, 2009.

Departemen Agama RI. Al-Qur'an dan Tafsirnya, jil. II. Cet. III; Jakarta: Departemen Agama RI, 2009.

Departemen Agama RI. Al-Qur'an dan Tafsirnya, jil. V. Cet. III; Jakarta: Departemen Agama RI, 2009.

Departemen Agama RI. Al-Qur'an danTafsirnya, jil. X. Cet. III; Jakarta: Departemen Agama RI, 2009.

Departemen Pendidikan Nasional. Kamus Besar Bahasa Indonesia. (t.c.); Jakarta: Pusat Bahasa Departemen Pendidikan Nasional, 2008.

Dinas Kebudayaan dan Pariwisata Kabupaten Bone.Sejarah Bone. Watampone: Dinas Kebudayaan dan Pariwisata, 2007.

Fat urochman.Pengantar Psikologi Sosial. Yogyakarta: Pinus, 2006.

Ibn Kathīr. Mukhtașar Tafsīr Ibn Kathīr. Terj. Salim Bahreisy dan Said Bahreisy.Terjemah Singkat Tafsir Ibnu Katsier,jil. III. Cet. I; Kuala Lumpur: Victory Agencie, 1988.

Jalaluddin.Filsafat Pendidikan Islam; Telaah Sejarah dan Pemikirannya.Jakarta: Kalam Mulia, 2011.

Al-Jazairī, Syaikh Abū Bakar Jabīr.Aisar al-Tafăsir li al-Kalāmi alAliyyi al-Kabīr.Terj. M. Azhari Hatim dan Abdurrahim Mukti, Tafsir Al-Qur'an Al-Aisar, jil. II. Cet. II; Jakarta: Darus Sunnah, 2011.

Machmud, A. Hasan. Silasa I. Cet. III; Makassar: UD. Indah Jaya, 2001.

al-Maḥallī, Jalāluddīn Muhammad Ibn Aḥmad. dan Jalāluddīn 'Abdurraḥmān Ibn Abī Bakr al-Suyūṭ̂, Tafsìr al-Qur'ān al'Azīm, juz I. Surabaya: al-Hidayah, (t.th.).

al-Marāghī, Aḥmad Mușțafā.Tafs̄ir al-MarāghīiTerj. Bahrun Abubakar, et. al. Terjemah Tafsir al-Maraghi, jil. I. Cet. II; Semarang: CV. Toha Putra Semarang, 1992.

. Tafsìr al-Marāghīi.Terj. Bahrun Abubakar. et. al. Terjemah Tafsir al-Maraghi, jil. VI. Cet. I; Semarang: Tohaputra, 1987. . Tafsìr al-Marāghī. Terj. Bahrun Abubakar, et. al. Terjemah Tafsir al-Maragi, jil. XXVIII. Cet. II; Semarang: CV. Toha Putra, 1993. 
Mattulada.Latoa: Satu Lukisan Analitis terhadap Antropologi Politik Orang Bugis. Cet. II; Makassar: Hasanuddin University Press, 1995.

Muḥammad Ibn Ismā‘īl Ibn Ibrāhīm Ibn al-Mugīrah Ibn Bardiżbah, Kitab Bukhari, dalam Ensiklopedia Hadis [CD ROM], PT Kreasi Riset Informatika Sistem Solusi (Keriss), (t.th.), hadis no. 2811.

Munawwir, Ahmad Warson.Al-Munawwir: Kamus Arab-Indonesia Terlengkap. Cet. XXV; Surabaya: Pustaka Progressif, 2002.

Pelras,Christian. The Bugis.Terj. Abdul Rahman Abu, et. al. Manusia Bugis. Cet. I; Jakarta: Nalar, 2006.

al-Qurțūbi, Syaikh Imām. al-Jāmi' li Ahkām al-Qur'ān. Terj. Ahmad Khotib. Tafsir Al Qurthubi, jil. VI. Cet. I; Jakarta: Pustaka Azzam, 2008.

Quṭb, Sayyid. FīZilāl al-Qur'ān. Terj. As'ad Yasin. Tafsir Fi Zhilalil Qur'an: Di Bawah Naungan Al-Qur'an, jil. V. Cet. I; Jakarta: Gema Insani Press, 2002.

Rahim, A. Rahman. Nilai-Nilai Utama Kebudayaan Bugis.Cet. III; Makassar: Hasanuddin University Press, 1992.

al-Ṣābūn̄̄, Syaikh Muḥammad 'Ālī. Șafwah al-Tafāsīr.Terj. KH. Yasin, Shafwatut Tafasir: Tafsir-tafsir Pilihan, jil. II. Cet. I; Jakarta: Pustaka Al-Kausar, 2011.

Shihab M. Quraish. Tafsir Al-Mishbāh: Pesan, Kesan dan Keserasian Al-Qur'an, vol. I. Cet. I; Ciputat: Lentera Hati, 2001. .Tafsir Al-Mishbāh: Pesan, Kesan dan Keserasian Al-Qur'an, vol. XIV. Cet. I; Ciputat: Lentera Hati, 2001.

Subagyo. "Pengembangan Nilai dan Tradisi Gotong Royong dalam Bingkai Konservasi Nilai Budaya" Idonesian Journal of Concervation (IJC) 1, no. 1 (2012): h. 61-68.

Sudaryono.Metodologi Penelitian. Cet. I; Jakarta: Rajawali Pers, 2017.

al-Ṭabarī, Abū Ja'far Muḥammad Ibn Jarīr. Jāmi ' al-Bayān an Ta’w̄̄l Ayi al-Qur'ān. Terj. Akhmad Afandi, Tafsir Ath-Thabari, jil. XXV. Cet. I; Jakarta: Pustaka Azzam, 2008.

Taufik.Empati Pendekatan Psikologi Sosial. Jakarta: Rajawali Pers, 2012.

Teng, Muhammad Bahar Akkase. "Falsafah Hidup Orang Bugis (Studi Tentang Pappaseng Kajaolaliddong di Kabupaten Bone)". Disertasi (Makassar: PPs UIN Alauddin, 2019). 